Title: Widening the Net: China's Anti-Terror Laws and Human Rights in the Xinjiang Uyghur Autonomous Region

Author: Dr Michael Clarke

Affiliation: Research Fellow, Griffith Asia Institute, Griffith University Brisbane, Australia. Email: m.clarke@griffith.edu.au

Biography: Dr Michael Clarke is currently a Research Fellow at the Griffith Asia Institute, Griffith University, Brisbane, Australia. His research expertise and interests concern Chinese and Central Asian history and politics, China's ethnic minorities, contemporary Chinese foreign policy, US foreign policy and nuclear proliferation in the Asia-Pacific. 


\title{
Widening the Net: China's Anti-Terror Laws and Human Rights in the Xinjiang Uyghur Autonomous Region
}

\begin{abstract}
Although a significant amount of attention has been paid to the implementation of anti-terror laws and their impact on human rights in the West, relatively little has been paid to this issue in the Chinese context. China has not been entirely immune from the anti-terror legislative wildfire generated by 9/11. I argue that the international dynamic of privileging security concerns over protecting human rights is prevalent in China and is acutely felt in the specific regional context of the Xinjiang Uyghur Autonomous Region. China's anti-terror laws contribute not only to further human rights violations in Xinjiang but also hold the potential to criminalize dissent throughout the PRC via the application of an ambiguous and expansive definition of terrorism.
\end{abstract}

Keywords: China; Xinjiang; Uyghurs; anti-terror laws; human rights

While 9/11 proved to be catalytic in accelerating the Bush administration's turn towards unilateralism in its foreign policy and the implementation of a strategic doctrine based on pre-emption (or more correctly prevention), it also generated what one observer termed a 'legislative wildfire' amongst governments the world over to enact legislation to better detect, prevent, prosecute and eradicate terrorism. ${ }^{1}$ Much scholarly attention has been paid to the implications of this legislative wildfire for the protection of human rights in the context of the US, Europe and Australia but relatively little on the strength, scope and implications of this consequence of 9/11 throughout Asia. One particular lacuna in this context concerns the relationship between anti-terror laws and human rights in the People's Republic of China (PRC). This dearth of attention to the China context is arguably due to a general perception that China has no 'real' threat posed to it by terrorism and that its authoritarian government ultimately has little practical need to enact legislation to confront and suppress terrorism. 
Yet, as this paper will demonstrate, China has not been entirely immune from the legislative wildfire generated by 9/11 nor from the core tension between national security and human rights protection that has been evident across the world. Indeed, the key criticism levelled at governments in the West post-9/11, particularly in the US and UK, has been that national security or anti-terror laws have tended to erode standards of human rights protection. This concern has been even greater in relation to non-democratic states such as China, with various Western governments and nongovernmental organisations such as Amnesty International accusing Beijing of utilising post-9/11 international concern with terrorism as an excuse to tighten controls on society and clamp down on dissent. ${ }^{2}$

I argue that while this dynamic of privileging security concerns over protecting human rights is prevalent in China, it is one that is acutely felt in a specific regional context that has broad implications for China's domestic politics and international relations. As will be noted below, China's terrorist problem is largely isolated to the Xinjiang Uyghur Autonomous Region in the far north-west of the country. Moreover, the central charge levelled against prominent Western governments - i.e. that national security/anti-terror laws have eroded the protection of individual human rights - is one that needs to be tempered in the context of Xinjiang by noting that the impact of anti-terror laws/national security laws has simply been to widen the scope for the state's suppression of real and imagined threats to national security. This ultimately has resulted in further violations of individual human rights not only within Xinjiang but in the neighbouring Central Asian states in which significant numbers of Uyghurs reside. 
China's response to the issue of terrorism post-9/11 has operated at two levels. Internationally, Beijing has reconfigured its discourse regarding Xinjiang and the Uyghurs to reflect the contemporary international focus on Islamist-inspired terrorism and extremism in order to gain international recognition of its 'legitimate' struggle against Uyghur terrorism. China's efforts in this regard should be seen as a continuation of a long-term struggle to integrate this ethnically diverse region. Domestically, the 'war on terror' has permitted China to not only deploy significant repressive force, in political, legal and police/military terms, to confront the perceived threat to Xinjiang's security posed by Uyghur terrorism but also to establish the political and legal framework through which to confront any future challenges to state power. This latter aspect can be seen in Beijing's increasing tendency to label not only dissenting Uyghurs but also Tibetans, Falun Gong members, and even protesting workers/peasants as 'terrorists'. China has moved toward the achievement of these goals through three main avenues: amendments to China's criminal law; the deployment of an expansive definition of 'terrorism'; and security and counter-terror cooperation with the states of the Shanghai Cooperation Organization (SCO) and rhetorical support for the US 'War on Terror'.

\section{Chinese Policy and 'Terrorism' in Xinjiang}

Over a long period of time - especially since the 1990s - the "East Turkistan” forces inside and outside Chinese territory have planned and organized a series of violent incidents in the Xinjiang Uygur Autonomous Region of China and some other countries, including explosions, assassinations, arsons, poisonings, and assaults, with the objective of founding a so-called state of "East Turkistan". These terrorist incidents have seriously jeopardized the lives and property of the people of all ethnic groups as well as social stability in China, and even threatened the security and stability of related countries and regions. ${ }^{3}$ 
For many casual foreign observers, China's claim outlined in the January 2002 document cited above, that it too confronted a serious terrorist problem amounted to a cynical, opportunistic act to justify to international opinion its ongoing suppression of autonomy movements amongst its many ethnic minorities. Indeed, China's prompt declaration of support for the Bush administration's 'War on Terror' after the events of 11 September 2001 was also perceived as the product of a rational calculus in Beijing as to what political and strategic benefits China could obtain through support for and cooperation with US anti-terror efforts. In short, the events of 11 September 2001 were seen to offer China the twin opportunities to intensify and legitimate its often harsh response to signs of ethnic minority unrest in Xinjiang and reduce tensions in its relations with Washington that had been accentuated since the election of President George W. Bush in $2000^{4}$.

However, it needs to be recognized that China's efforts to prevent the separation of Xinjiang from the People’s Republic date to the People’s Liberation Army's 'peaceful liberation' of the region in 1949. Indeed, one of the most salient, and often forgotten, features of contemporary China that contributes significantly to Beijing's excessive concern with state security is the political, strategic and cultural significance of its diverse population. Thus, although the fifty-five officially recognised ethnic minorities constitute only eight and a half per cent of China's population according to the 2000 census, they are predominantly concentrated in China's border regions such as Xinjiang and Tibet. ${ }^{5}$ The security implications of China's ethnic minorities vary due to a number of important factors such as geographic concentration and varying degrees of acculturation to the dominant Han society. Furthermore, the fact that some are widely dispersed throughout China and others are primarily concentrated in 
strategic regions along China's periphery, results in differing interpretations and analyses regarding the security challenges posed by the various ethnic groups. From Beijing's perspective, however, the situation of the Uyghur in Xinjiang presents it with a series of incomparable, potentially troublesome characteristics. First, the Uyghur are the dominant ethnic group in Xinjiang, comprising some $43 \%$ of the population, and are primarily concentrated within the bounds of this administrative unit. Second, the Uyghur are predominantly Muslim in religious confession. Third, a substantial number of Uyghur currently reside in the neighbouring Central Asian republics, in particular Kazakhstan and Kyrgyzstan. Fourth, the Uyghur have a recent history of separation, and some would argue even independence, from the Chinese state. $^{6}$

These demographic, geographic and political factors have converged since the establishment of the People's Republic to make Xinjiang a particularly problematic issue for Beijing. Historically, the geopolitical position of the region as a 'Eurasian crossroad' combined with the ethno-cultural dominance of Turkic and Mongol peoples to result in only intermittent periods of Chinese predominance and control. ${ }^{7}$ Since 1949, however, the Chinese state’s strategy toward Xinjiang has been framed by the overall goal of integration - that is by the quest to not only consolidate China's territorial control and sovereignty over the region but to absorb, politically, economically and culturally, the various non-Han ethnic groups of Xinjiang into the 'unitary, multi-ethnic state' of the PRC. ${ }^{8}$ The instruments by which Beijing has sought to achieve this goal have remained relatively consistent since 1949 - the establishment of military-agricultural colonies (through the instrument of the paramilitary Xinjiang Production and Construction Corps), encouragement of Han 
colonization, state control and management of religious expression and institutions, and cooptation of ethnic minority elites. ${ }^{9}$

China became more concerned regarding the security of Xinjiang with the collapse of the Soviet Union in 1991 due to the convergence of external dynamics such as the Islamic revival in neighbouring Central Asia and Afghanistan and internal dynamics associated with China's post-1978 reform era. China's strategy to manage these dynamics since the collapse of the Soviet Union has rested upon the development of a “double-opening” approach to simultaneously integrate Xinjiang with Central Asia and China proper in economic terms and to establish security and cooperation with China's Central Asian neighbors. Internally, this agenda has resulted in increased central government investment, particularly regarding construction and infrastructure projects (especially energy-related), and enhanced government control and management of ethnic minority religious and cultural practices. ${ }^{10}$ Externally, China's foreign policy in Central Asia has reflected the ascendancy of this goal of integration for Xinjiang, with an emphasis placed on the establishment of political, economic, and infrastructural links with the Central Asian states, particularly Kazakhstan and Kyrgyzstan. $^{11}$

Although some observers have emphasized the importance of external developments in generating cycles of Uyghur opposition since 1990, it is clear that Chinese policy has also played a key role in this regard. ${ }^{12}$ Although the establishment of political, economic, and cultural linkages with Central Asia are seen as vital to the success of the state's development and integration strategy for Xinjiang, they are simultaneously viewed with suspicion as a potential source of threat to this very process due to the 
region's recent history of trans-border ethno-religious movements such as the “Islamic Movement of Uzbekistan” (IMU) and the Taliban. ${ }^{13}$ The contradictory nature of this position compelled China to seek a broader regional approach to issues of regional economic cooperation, ethnic separatism, drugs and weapons trafficking, radical Islam, and border security that culminated in the creation of the "Shanghai Five” in 1996 and its eventual transformation into the Shanghai Cooperation Organization (SCO) in June 2001. ${ }^{14}$ Despite China's success in establishing greater security cooperation with the Central Asian members of the SCO, Xinjiang has nonetheless seen continued outbursts of Uyghur dissent. Importantly, there also developed connections between a small, and arguably marginal, number of Uyghurs and violent Islamist groups in Central Asia and Afghanistan such as the IMU and the Taliban. $^{15}$

Major elements of China's strategy in the region, such as increased migration of Han and increased state control/management of ethnic minority religious and cultural expression, have been major ongoing sources of Uyghur grievance against the state. ${ }^{16}$ The state's response to this has consisted of a alternating periods of 'soft' and 'hard' policies toward ethnic minority religious and cultural expression. The 'soft' approach has been characterised by a relative tolerance and even encouragement of institutionalised Islam - through such measures as state-funding for mosque construction and the activities of the state-controlled Chinese Islamic Association when it is perceived as necessary to gain the acquiescence of the Uyghur population. The 'hard' policies in contrast have been characterised by campaigns against religious education outside of state-sanctioned institutions, 'illegal' mosque construction, and the 're-education' and 'reform' of religious leaders when the state perceives Islam to 
be a threat to security. The close link between Islam and Uyghur identity has meant that any attempt by the state to regulate religious practice and expression is ultimately a cause of resentment for the Uighur and is often perceived as an attempt to weaken Uighur identity. For the state, however, heightened Islamic consciousness, if not adequately managed, is perceived to be at the root of outbreaks of opposition and violence. $^{17}$

This cycle was evident throughout the 1990s, with the authorities instituting regular "Strike Hard" campaigns in the region. In the rest of China "Strike Hard” campaigns are focused upon achieving accelerated arrests, trials and sentencing of criminals but in Xinjiang they are directed to a substantial degree against "national separatists" and “illegal religious activities". 18 'Strike Hard' campaigns in Xinjiang often result in accelerated trials and increases in the use of the death penalty with Vicziany, for example, noting that between 1997 and 1999 Uyghurs who represent only 1 per cent of China's population accounted for between 3 and 4 per cent of all executions in the country. ${ }^{19}$ Moreover, this cycle has continued into the early $21^{\text {st }}$ century, with the "hard” approach and associated "Strike Hard” campaigns re-implemented from late 2001 onward after the events of 9/11. ${ }^{20}$ Indeed, Human Rights Watch in its 2005 report on religious repression in Xinjiang reported that over 200 people had been executed for 'state security crimes' in the region since $1997 .^{21}$

The capture of twenty-two Uyghurs in late 2001 and early 2002 by the US military during ‘Operation Enduring Freedom' in Afghanistan and their subsequent detention at Guantanomo Bay in Cuba was seized upon by Beijing as evidence that it too confronted the 'three evils of terrorism, extremism and separatism' in Xinjiang. ${ }^{22}$ 
Accompanying this turn of events was a change in rhetoric of the Chinese government whereby Beijing did not fail to discuss events in Xinjiang without reference to the 'war on terror', ‘terrorism’ or 'extremism'. Although this tendency had been present prior to 9/11, particularly within the context of China's diplomacy toward the Central Asian states and the multilateral SCO, it was now a central element of its public international diplomacy. ${ }^{23}$ China was also quick to support the US-led 'war on terror' through voting for a anti-terrorism resolution in the United Nations Security Council, supporting Pakistan in its pro-United States efforts against Osama bin-Laden, providing intelligence information on terrorist networks and activities in the region and freezing the accounts of terrorist suspects in Chinese banks. ${ }^{24}$

These efforts bore significant fruit for Beijing with the US Deputy Secretary of State Richard Armitage announcing in August 2002 that the US would officially list the 'East Turkestan Islamic Movement' as an international terrorist organisation, a lead which the UN subsequently followed. ${ }^{25}$ For many critical observers, however, these developments suggested that as in numerous other cases throughout the world, national and international security - narrowly defined as ensuring the security of sovereign states - had taken precedence over the promotion and protection of universal human rights standards. ${ }^{26}$ It is to this international dynamic and its implications for human rights in China, and Xinjiang in particular, that we now turn.

\section{The International Context: Toward the Criminalisation of 'Terrorism'}

The contempt shown for human rights during World War II compelled the international community to question the assumption that the principle of noninterference in the domestic affairs of states was a central and immutable component 
of international order. Thus, we have seen since 1945 the establishment of two core human rights conventions - the International Covenant on Economic, Social and Cultural Rights and the International Covenant on Civil and Political Rights - which a significant number of UN members have signed and ratified. Overall the general trajectory in the realm of human rights protection has been an upward one, whereby the assumption that modern, legitimate statehood requires the protection of basic individual human rights has become embedded. The events of 9/11 and the reactions of some of the world's most powerful states has, however, arguably reversed this trajectory with the privileging of the security of the state and its citizens over that of the protection of individual human rights. ${ }^{27}$ Internationally, government responses to the attacks of 9/11 have ranged from the introduction of rafts of new legislation, cross-institutional intelligence sharing, and a renewed emphasis on law enforcement combined with some efforts at constructing multilateral or regional approaches to counter-terrorism. ${ }^{28}$ Some governments, the UK for example, have simply increased their use of tools that they have historical deployed against domestic subversives or suspected terrorists such as administrative detention without criminal charge or trial. Meanwhile other governments have revised or implemented special security courts to handle suspected terrorists or expanded the definition of terrorist-related acts under their criminal codes. ${ }^{29}$

Significantly, governments have relied upon domestic legal responses to terrorism to confront what is widely accepted to be an international problem. The core problem in attempts to forge an international response, particularly through the United Nations, has revolved around debates over the relative merits of a focus on addressing the ‘underlying causes' of terrorism or criminalisation of terrorism. The dilemma here has 
been obvious. If one focuses on addressing the 'underlying causes' of terrorism it is possible to perceive acts of terrorism against a racist or occupying state for example as legitimate political violence. If, however, one prefers to criminalise acts of terror themselves then political or any other motives behind the acts become irrelevant 'strict criminalisation means that the act is criminal notwithstanding the motives behind it'. ${ }^{30}$ Since 9/11 the divide between states focusing on one or the other of these positions has arguably become sharper. Many western states, particularly the US and UK, have actively advocated a strict legal regime to prosecute terrorists based on the principle that these acts be proscribed as terrorist in nature regardless of their motives. Other states, particularly those in the developing world, have in contrast rejected this position arguing that it fails to take into consideration terrorism as a legitimate political tactic in movements for self-determination. ${ }^{31}$

This fundamental disagreement has in the past resulted in previous international agreements relating to acts of terrorism affirming the right of self-determination. The 1979 UN Convention against the Taking of Hostages, for example, states in its preamble that the states party to the convention reaffirm, 'the principle of equal rights and self-determination of peoples enshrined in the Charter of the United Nations'. ${ }^{32}$ Due to the events of 9/11, however, more recent UN conventions and resolutions have replaced the affirmation of the right to self-determination with unequivocal statements criminalising acts of terrorism. This change can be seen for example in the text of the UN General Assembly resolution 'Measures to Eliminate International Terrorism’ of January 2002 which states that the assembly:

Reiterates that the criminal acts intended or calculated to provoke a state of terror in the general public, a group of persons for political purposes are in any circumstances unjustifiable, whatever the considerations of a 
political, philosophical, ideological, racial, ethnic, religious or other nature that may be invoked to justify them. ${ }^{33}$

This seeming victory for the criminalisation of terrorism has, however, also been hampered by the failure of the international community to determine what constitutes legitimate violence or criminal terrorism, thus preventing the development of a widely accepted definition of terrorism. ${ }^{34}$

These two broad effects of $9 / 11$ on the international response to terrorism are particularly relevant to China. The ascendancy of the criminalisation dynamic has permitted Beijing to amend its Criminal Code to widen the scope of acts and offences that can be defined as terrorism with a deleterious result for the individual political rights of Chinese citizens. Another important element in China's response to terrorism has been the conclusion of extradition treaties between itself and such states as Kazakhstan, Kyrgyzstan, Tajikistan, Pakistan and Nepal, which has enabled it to target alleged Uyghur 'terrorists' residing in those states. ${ }^{35}$ Furthermore, the absence of any UN-sanctioned definition of what constitutes terrorism has enabled Beijing to develop an expansive definition of terrorism that includes many actions that elsewhere would not fall under the label. This is not to imply too sanguine a view of the likely impact of such a development within the UN but rather to note that Beijing, as a self-consciously 'rising' power in the international system has become increasingly concerned with ensuring that it is seen to uphold the existing international order. ${ }^{36}$ Thus, as a number of observers have noted, much of China’s diplomacy is focused on portraying contemporary China as a 'normal' state in contrast to the radical, outlier state, that it was during the Maoist era and an important element of this concerns China's commitment to prevailing international norms and 
regimes such as the Non-Proliferation Treaty or UN human rights standards. ${ }^{37}$ Nonetheless the overall impact of these two developments in the context of Xinjiang has been for the Chinese authorities to effectively 'widen the net' to ensnare many Uyghurs on the basis of 'terrorism' charges.

\section{Widening the Net: Expanding the Definition of 'Terrorism' in the PRC}

On December 29, 2001 the Standing Committee of the $9^{\text {th }}$ National People’s Congress of the PRC adopted a number of major amendments to the Criminal Law of the PRC. The stated purpose of these amendments was, 'to punish the crimes of terrorism, safeguard the security of the State and of people's lives and property and maintain public order'. ${ }^{38}$ While China's Criminal Law prior to these amendments already contained provisions, under the section of the law pertaining to 'Crimes of Endangering Public Security', to punish various 'terrorist crimes', the new amendments reflected an international tendency to expand the definition of acts of 'terrorism' and to increase punitive measures. Moreover, as I will discuss below, this dynamic has arguably undermined further the protection of individual human rights in China. As such it can be suggested that China has followed the international trend, noted above, toward favouring the criminalisation of 'terrorism' regardless of the motives that may underpin such acts. A further cause for concern regarding the impact of these amendments on human rights protection in China is the absence of a consistent definition of 'terrorism' within the Criminal Law. The major changes wrought by the amendments concern widening the scope of actions that are now criminalised as 'terrorist' acts, along with increases in punitive measures. I will now summarise the major changes made by these amendments and their implications for individual human rights. 
Amendments of 29 December 2001 to the Criminal Law of the PRC ${ }^{39}$ :

- Article 114 revised to stipulate a fixed-term sentence of 'not less than 3 years but not more than 10 years' for persons responsible for 'arson', 'explosions', the spread of 'poisonous or radioactive substances or infectious diseases' or 'other dangerous means' that endangers public security but causes 'no serious consequences'.

- Article 115 revised to stipulate a fixed-term of 'not less than 10 years' imprisonment for persons responsible for, 'serious injury or death on people or causing heavy losses of public or private property' through such actions as identified in Article 114.

- The first amendment to Article 120 states that a person who, 'forms or leads a terrorist organization shall be sentenced to fixed-term imprisonment of not less than 10 years or life imprisonment'. Those persons who, 'actively participate in a terrorist organization' are to be imprisoned to fixed-term of 'not less than 3 years'.

- The second amendment of Article 120 states that, 'Whoever provides funds to any terrorist organization or individual who engages in terrorism' is to be sentenced to fixed-term imprisonment of 'not more than 5 years'.

- Article 125 revised to stipulate fixed-term imprisonment of 'not less than 5 years’ for persons who, 'illegally manufactures, trades in, transports or stores poisonous or radioactive substances...thereby endangering public security’

- Article 127 revised to stipulate fixed term imprisonment of 'not less than 10 years, life imprisonment or death' for persons who steal 'ammunition, explosives' or other dangerous substances from 'State organs' 
- Article 191 revised to stipulate fixed term imprisonment of 'not more than 5 years' or 'criminal detention' for illegal financial operations or gains connected to 'drug related crimes or from crimes committed by organizations in the nature of criminal syndicates, crimes of terrorism or crimes of smuggling'.

- New clause added to Article 291 that stipulates fixed-term imprisonment of 'not more than 5 years' for persons who 'disturb social order' by gathering in public places, block traffic or obstruct agents of the State. This clause also stipulates the same punishment for persons who spread 'hoaxes of explosive, poisonous or radioactive substances' or fabricate 'terrorist information'. However, if 'the consequences are serious' the sentence will be a fixed-term of 'not less than 5 years'.

What are the implications for human rights in China of these amendments to the Criminal Law? Perhaps most troubling for human rights advocates such as Amnesty International is that these amendments increase the scope for the use of the death penalty in China. ${ }^{40}$ For example, as noted above Articles 115, 125 and 127 carry punishments that range from terms of imprisonment to the death penalty for crimes ranging from 'arson' to illegally manufacturing or transporting 'poisonous or radioactive substances'. The amendments to Article 120 meanwhile suggest a turn not only towards the criminalisation of 'terrorism' but also of political dissent in general. First, the amendments make it a criminal offence to be a member of a 'terrorist organization' whether or not any other illegal act is committed. The failure to define what constitutes a 'terrorist organization' leaves the door open for this law to be deployed against any groupings, organizations or religious associations that the state 
deems to be a threat whether they be political or non-political or non-violent. Moreover, the second amendment of Article 120 also fails to specify a maximum sentence thus potentially making it a capital offence to be charged with 'funding of a terrorist organization'. Ultimately, the amendments to Article 120 provide an expansive list of potential 'terrorist' crimes without providing a concrete definition of terrorism with which to judge potential acts of the 'terrorists'.

Article 191 and the new clause to Article 291 also reflect this trajectory towards the criminalisation of dissent. Article 191 for instance makes it a criminal offence to be connected financially to acts the state deems to amount to 'terrorist crimes'. Moreover, the new clause to Article 291 also holds the potential to criminalise the dissemination of information and public meetings or associations. Indeed, Amnesty International reports that Article 291 has in the past been used to punish people peacefully exercising the right to free expression through peaceful public gatherings or demonstrations. ${ }^{41}$ As with a number of the previous articles, the new clause to Article 291 also fails to specify a maximum sentence or to clearly define 'serious consequences'. Thus, this new clause raises the possibility that those persons convicted of the offences specified may face the death penalty if the acts are deemed to have caused 'serious consequences'.

Moreover, the criteria by which the China's political authorities judge 'terrorist' crimes, revealed by the Deputy Director of the Counter-Terrorism Bureau of the Ministry of Public Security, Zhao Yongchen, in December 2003, are also ambiguous and expansive in nature. According to Zhao terrorist organizations:

...have their headquarters either inside or outside Chinese territory, would be engaged in terrorist activities involving violence and terror and causing 
harm to state security, social stability, lives and property. Secondly, they would have established leadership and organizational structures with specialized roles within the structures. ${ }^{42}$

Beyond this the organization must satisfy one of the following criteria in addition to the first two:

1) Currently or previously involved in the organization, planning, instigation, conduct or implementation of terrorist activities; 2) Financing and supporting terrorist activities; 3) Building bases used for terrorist activities or organizing, recruiting and training terrorists; and 4) Collaborating with international terrorist organizations by receiving finance or training from these organizations or engaging in terrorist activities with them. ${ }^{43}$

Meanwhile ‘terrorists’ according to Zhao are defined as:

...people who have significant relationships with terrorist organizations engaged in terrorist activities harmful to state security or the lives and property of people inside or outside Chinese territory. This would apply irrespective of whether or not they have become naturalized citizens of foreign countries. ${ }^{44}$

In addition to this, one must meet one of the following criteria to be deemed a

'terrorist':

1) Organizing, commanding or engaged in terrorist activities; 2) Organizing, planning, propagating, or instigating the implementation of terrorist activities; 3) Financing and supporting terrorist organizations or terrorists to assist them in the conduct of terrorist activities; and 4) Funded or trained by a terrorist organization or other international organization to engage in terrorist activities. ${ }^{45}$

Thus, China's response to terrorism post-9/11 is characterised by three major issues that raise concern regarding their impact on human rights:

- A lack of precision regarding what constitutes 'terrorism'

- The provisions under these articles hold the potential to criminalize a wide range of activities, including peaceful expressions of dissent or opposition to the state

- The death penalty may be applied under the majority of the amendments 


\section{Implications for Human Rights in Post-9/11 Xinjiang}

Although, as I have noted above, China's struggle against 'splittists' and 'separatists' in Xinjiang pre-dates the events of 9/11, Beijing nonetheless promptly adopted the rhetoric of the 'war on terror' to justify its ongoing repression of Uyghur opposition. This can be seen in China's diplomatic offensive since 9/11 within the context of its relations with the members of the SCO and with the US and in government statements regrading either the 'war on terrorism' or the situation in Xinjiang. ${ }^{46}$ Domestically, it has also made use of the post-9/11 amendments to the criminal law to intensify its crackdown on Uyghur dissent and opposition. While it is clear widespread human rights violations took place in Xinjiang throughout the 1990s, especially during the regular 'Strike Hard' campaigns, the available evidence suggests that the authorities have applied the new provisions in a draconian manner with deleterious consequences for individual human rights. Moreover, China's extradition agreements with neighbouring states have permitted it to forcibly repatriate alleged Uyghur 'terrorists' residing in foreign countries. Both Amnesty International and Human Rights Watch in reports on the situation in Xinjiang have estimated that 'thousand' of Uyghurs were arrested or detained under the new amendments between 2001 and 2005, corroborating claims made by Uyghur émigré organisations as to the scale of the crackdown. ${ }^{47}$ Indeed, the scale of arrests suggested by these reports was confirmed by the official Xinjiang Ribao newspaper when it reported in early 2006 that authorities had arrested 18, 227 people in Xinjiang for 'endangering national security' over the previous twelve months alone. ${ }^{48}$ 
However, the number of suspects who were subsequently charged and sentenced is difficult to ascertain due to the lack of transparent reporting on judicial proceedings in Xinjiang. Nonetheless, the available information regarding the issue of the charges levelled against individuals and their subsequent sentences reflect the three major concerns with the new anti-terror laws noted at the end of the previous section - i.e. an imprecise definition of terrorism; the criminalization of a wide variety of activities; and broadening the potential for use of the death penalty. For example, according to a list compiled by the China Rights Forum, from 25 September 2001 to March 2003 thirty-six Uyghurs were arrested and variously charged with crimes ranging from ‘illegal religious activities', 'political offenses', 'teaching the Koran', 'possession of wrong books', to 'organizing and leading a terrorist organization'. Of these individuals, seven were sentenced to death, four were sentenced to 10 to 20 years imprisonment, and nine were sentenced to 1 to 10 years imprisonment. ${ }^{49}$ The crimes that these individuals were charged with demonstrate the wide range of activities that the state has criminalized in the service of national security, including expressions of ethnic identity such as religious observance. ${ }^{50}$

In this latter respect Human Rights Watch has detailed renewed repression of overt religious observance through such measures as increased control over the registration and operation of religious organizations, tightened controls over religious publications, and imposition of heavier sanctions and penalties for breaking these regulations. ${ }^{51}$ Of particular importance has been the state’s renewed campaign against what it defines as 'illegal religious activities'. Indeed, it is clear that the authorities view religious observance in Xinjiang as a threat to national security with former President Jiang Zemin stating in December 2001 that, 'We will never allow the use of 
religion to oppose the Party's leadership and the socialist system or undermine the unification of the state and unity among various nationalities'. ${ }^{52}$ Citing an Urumqi municipality 'Manual for Ethnic and Religious Work', which states that the manual's purpose is 'to be used to conduct education and serve cadres for nationalities religious affairs in their work', the Human Rights Watch report details that there are sixteen major actions that are defined as 'illegal religious activities':

1. Compelling people to believe

2. Compelling people to participate in religious activities

3. Privately organizing religious study schools

4. Using religion to meddle in administration, justice and education, weddings, family planning or cultural activities

5. Without having obtained authorization, engaging in religious activities spanning different localities or organizing other religious activities

6. Beautifying, revamping or enlarging places for religious activities without having obtained authorization

7. Restoring abolished religious feudal privileges and oppressive exploitative systems

8. Printing religious propaganda material without authorization

9. Receiving foreign contributions from religious organizations and individuals without authorization

10. Going abroad to study religion or carrying out religious activities in conjunction with foreign religious organizations without authorization

11. Privately setting up a religious "spot" and conducting proselytism without registration and authorization

12. Slandering the authorities, plotting to murder patriotic religious figures, fighting against the leading authorities of religious places and organizations, premeditatedly evading supervision, and stirring up trouble

13. Engaging in religious infiltration, setting up religious organizations, conducting proselytism and so on, by hostile enemy forces

14. Advocating "holy war," inciting religious fanaticism, developing religious extremist forces, spreading rumors, distorting history, advocating separatism, opposing the Party and the socialist system, 
sabotaging social stability or the unity of nationalities, inciting the masses to illegally rally and demonstrate, attacking the organs of the Party, government, army or public security

15. Using religion to breed separatist elements and reactionary backbone elements or to establish reactionary organizations; to carry out other activities that are harmful to the good order of society, production and life, and to criminal activities

16. Spreading evil cults. ${ }^{53}$

Beyond detailing a comprehensive will to control religious observance in Xinjiang, these proscriptions demonstrate not only a curtailment of the right to freedom of religious expression but also other basic civil and political rights. For instance, 'inciting the masses to illegally rally and demonstrate' is arguably aimed at controlling the freedom of assembly, 'distorting history' and 'using religion to meddle in administration, justice and education, weddings, family planning or cultural activities' compromises freedom of expression while the proscription against 'going abroad to study religion' tramples on freedom of movement. On this latter point, it has been widely reported that the authorities have recently placed severe restrictions on international travel for Uyghurs by confiscating passports. This has been done in order to prevent many Uyghurs from undertaking the annual pilgrimage to Mecca through other than state-sanctioned and supervised Hajj tours. Indeed, Wang Lequan in June 2007 specifically called on local authorities to harshly punish 'illegal pilgrimage organizers'. ${ }^{54}$ According to one anecdotal report, to qualify for official approval to undertake the Hajj one must meet a number of criteria including providing proof of no previous links to 'independence groups' or 'anti-Chinese activities' or, failing that, provide the relevant authorities with a 'fee' of up to 20, 000 yuan. ${ }^{55}$ 
These measures are symptomatic of a stepped up campaign against religious observance in Xinjiang. While this was evident in the past, particularly during the 'Strike Hard' campaigns of the 1990s as noted previously, 9/11 has evidently prompted the authorities to renew and intensify the measures through which it attempts to control religion in Xinjiang. As in the past, these measures not only targeted those deemed to be actively opposing the state but were also applied to religious and cultural practices that, in the state's perception, reinforced ethnic minority separateness from the Chinese state. Thus, Muslim clerics and students were arrested or detained for participation in "illegal religious activities," "illegal religious centers" closed, and imams compelled to attend "political education" sessions. Religious worship, education, or instruction has also been restricted to those 18 years of age and above, and a general discrimination against religious observance implemented. ${ }^{56}$

Official statements on the scale of arrests since 9/11 in the region have been rare. However a number have claimed that:

- 166 'terrorists and other violent criminals' were arrested by security forces between 20 September and 30 November $2001^{57}$

- 'Xinjiang suppressed a number of terrorist and separatist gangs, and arrested numerous criminals' over the 2003 to 2004 period (China News Agency $2004)^{58}$

- Authorities prosecuted 22 cases of groups and individuals for 'separatist and terrorist activities’ resulting in fifty sentences and an undisclosed number of executions between January 2004 and September $2004^{59}$ 
However, it is difficult for the international community to place much faith in the judicial process in Xinjiang as the courts in the region have reportedly been instructed that 'political criteria' should guide their work. Thus, an official account published on the website of the Supreme People's Court in 2003 asserted that 'political criteria come first in the combat against separatism’ in Xinjiang. ${ }^{60}$

The major themes of China's response to terrorism - the ambiguous nature of China's definition of terrorism, the criminalization of a wide variety acts, and the preeminence of political considerations - and their implications for human rights in Xinjiang is perhaps best exemplified by three prominent cases. The first, and most prominent case, concerns China's treatment of Rebiya Kadeer. Kadeer, a prominent and successful Uyghur businesswoman, was arrested in August 1999 on her way to a meeting with a delegation from the US Congressional Research Service. She was subsequently sentenced to eight years imprisonment in a secret trial in March 2000 for “providing secret information to foreigners” under Article 111 of the criminal law which concerns the 'illegal' provision of 'state secrets or intelligence for an organization, institution or personnel outside the country'. ${ }^{61}$ Kadeer's provision of 'state secrets' amounted to the distribution of copies of publicly available newspapers, the Kashgar Daily, Xinjiang Legal News and the Yili Evening News, to her husband living in exile in the US. Since her release in March 2005, Kadeer moved to the US where she has become a vocal advocate of the Uyghur cause for independence. ${ }^{62}$

The second and third cases, those of Uyghur poet Tursunjan Emet and author Nurmuhemmet Yasin, illustrates just how far the authorities have stretched the definition of terrorism to encompass nearly all forms of dissent against the Chinese 
state. On 1 January 2002 Emet recited an allegedly anti-government poem, at the end of a concert held at the Xinjiang People's Hall in the capital Urumqi. ${ }^{63}$ The poem was deemed to be 'inflammatory', 'advocated ideas of ethnic separatism' and had 'shown a strong tendency of opposing society, reality and the government' and Emet was subsequently detained for this 'ethnic separatist crime in the area of the ideological front' for a number of months. ${ }^{64}$ This subsequently compelled the authorities to launch a campaign against 'separatism in the ideological field' in Xinjiang, the logic of which was expressed by a vice-director of the office of the Xinjiang People's Congress who was reported to have declared that:

Xinjiang independence elements have changed their combat tactics since the September 11 incident. They have focused on attacking China on the ideological front instead of using their former frequent practice of engaging in violent terrorist operations. ${ }^{65}$

In February 2002 the Xinjiang CCP secretary Wang Lequan ordered authorities to be vigilant against 'separatist techniques’ in the ideological sphere which included:

- Using news media to propagate separatist thought

- Using periodicals, works of literature and art performances; presenting the subject in satires or allegories that give free reign to and disseminate dissatisfaction and propagate separatist thought

- Illegally printing reactionary books and periodicals; distributing or posting reactionary leaflets, letters and posters; spreading rumors to confuse the people; instilling the public with separatist sentiment

- Using audio and video recordings, such as audio tapes, CDs or VCDs, to incite religious fanaticism and promote "holy war"

- Forging alliances with outside separatist and enemy forces, making use of broadcasts, the Internet, and other means to intensify campaigns of reactionary propaganda and infiltration of ideas into public opinion

- Using popular cultural activities to make the masses receptive to reactionary propaganda encouraging opposition. ${ }^{66}$ 
The effect of this extension of the struggle against 'separatism' and 'terrorism' to the 'ideological sphere' has amounted to an attack on the rights of Xinjiang's ethnic minorities to engage in free expression. The subsequent case of Uyghur author Nurmuhemmet Yasin is illustrative of this point. Yasin was detained shortly after publishing a short story, 'Blue Pigeon', in the Kashgar Literature Journal, in November 2004. The story tells of a pigeon that travels far from home but when it returns home differently coloured pigeons capture it and imprison it in a birdcage. The blue pigeon subsequently commits suicide rather than submit to imprisonment. ${ }^{67}$ The authorities took this tale to be an allegorical attack on the government's policies in Xinjiang, in particular on the lack of real autonomy for the Uyghurs in what is officially the 'Uyghur Autonomous Region', and sentenced the author to ten years imprisonment for 'inciting terrorism' ${ }^{68}$ This campaign against perceived ideological separatism has also extended to a purge of state-controlled publications of 'separatist' themes and even public burning of confiscated literature. ${ }^{69}$ As Human Rights Watch has noted the Chinese authorities' determination that 'popular cultural activities' such as literature and poetry equate to 'separatism' or indeed 'terrorism', 'appears to be aimed at deterring people from engaging in activities that promote their history, culture or tradition' ${ }^{70}$

Finally, the case of Uyghur political activist and Canadian citizen Huseyin Celil, also demonstrates how effective China has been in developing security and counterterrorism cooperation with neighboring states, particularly those in Central Asia. Celil was arrested and extradited to China by Uzbek authorities in March 2006, where he was subsequently trialed in a closed court in Urumqi and convicted to life imprisonment for 'separatist activities' in June $2006 .{ }^{71}$ These activities according to a 
Chinese report included joining the 'East Turkstan Liberation Organization', acting as a 'senior instructor' for this group in Kyrgyzstan and providing funding of 80, 000 yuan (US \$10, 250) for the establishment of a new 'terrorist group'. ${ }^{72}$ Thus, Celil's offences fall under the two post-9/11 amendments to Article 120 of the criminal law of 'actively participating in a terrorist organization' and providing funding to a 'terrorist organisation'. China has also refused to acknowledge Celil's Canadian citizenship and thus permit Canadian consular personnel access to him as it claims he left Xinjiang 'illegally' in the early 1990s. ${ }^{73}$ Moreover, Celil's case is not an isolated one. In 2002, 2003 and 2004 China, by virtue of bilateral security agreements and police cooperation, extradited a significant number of alleged Uyghur 'separatists and terrorists' from Kazakhstan and Kyrgyzstan, Pakistan and Nepal. ${ }^{74}$ The subsequent fate of those extradited to China has been of grave concern to NGOs such as Amnesty International and Human Rights Watch, with Amnesty reporting that the majority of those returned have faced accelerated and closed trials and lengthy prison terms or the death penalty. ${ }^{75}$

\section{Conclusion}

In conclusion this paper has demonstrated that China has utilised international concern with terrorism to further its campaign against Uyghur separatism and dissent in the Xinjiang Uyghur Autonomous Region. It has also detailed that China has followed an international trend in relying upon domestic law and policing to combat terrorism with an emphasis on criminalising 'terrorism' without reference to motives that may underpin such acts. The net result in the Xinjiang context has been the further erosion of individual human rights of the region's ethnic minorities but particularly the Uyghur. In the wider national context of the People’s Republic, the 
changes to the criminal law hold the potential to criminalize dissent through the application of an ambiguous and expansive definition of terrorism. Meanwhile, China has arguably been successful in portraying its approach in Xinjiang as a response to 'international terrorism', particularly in its relations with the states of the SCO and to a lesser degree the US under the Bush Administration. In effect, the Chinese government has utilised the prevailing post-9/11 trend for privileging state security over individual human rights to augment its existing methods of political and social control in Xinjiang.

However, the impact of China's response to the events of 9/11 and the situation in Xinjiang on Beijing's international standing or reputation has been contradictory. On the one hand Beijing has followed an international trend toward the criminalisation of terrorism regardless of the motive, while on the other it has been perceived to have opportunistically used post-9/11 concern with terrorism to bolster the control of the party-state. The historical irony here, of course, is that Beijing no longer positions itself as the champion of 'national liberation' or 'self-determination' movements as it did during the 1960s and 1970s. Now China portrays itself as a 'responsible stakeholder' in the international system, a position that compels it to pursue policies of a conservative, status quo nature, such as privileging the security of the state. ${ }^{76}$ Yet, as the case of Xinjiang demonstrates, this heavy emphasis on an inherently conservative and Westphalian principles such as 'non-interference' in internal affairs and respect for state sovereignty is increasingly at odds with prevailing Western notions of the proper relationship between the state, society and security. Not coincidently these are principles which China has embedded in the pre-eminent multilateral organization in Central Asia, the SCO, which assists in Beijing's 
imperative to secure Xinjiang. ${ }^{77}$ The problem, as Gerlad Chan notes, is that China has become a staunch adherent of a traditional view of state sovereignty in an era of international politics where the practicality and indeed morality of such a position is increasingly questioned:

The irony, however, is that what China intends to maintain intact, such as a strict interpretation of state sovereignty in classical terms, is what the West wants to play down. The conflict lies in the fact that China is at pains to keep the traditional system of interstate relations in order to protect its sovereign interests, while the US acts like a 'revisionist power, working to change the existing world order to make allowance for humanitarian intervention, contrary to the classical understanding of sovereign rights and non-intervention in domestic affairs of another country. ${ }^{78}$

\section{NOTES}

${ }^{1}$ Joshua D. Zelman, 'Recent Developments in International Law: Anti-Terrorism Legislations - Part One: An Overview’, Journal of Transnational Law and Policy, Vol. 11, No. 1 (Fall 2001), p. 184.

${ }^{2}$ See for example, Amnesty International, People's Republic of China: Uighurs Fleeing Persecution as China Wages its 'War on Terror’, (New York: 2004), pp. 1-40.

${ }^{3}$ Information Office of the State Council of the PRC, 'East Turkistan Forces Cannot Get Away with Impunity', People's Daily, 21 January 2002, available at http://english.peopledaily.com.cn/200201/21/print20020121_89078.html. Accessed 30 November 2008.

4 See for example, Chien-pung Chung, “China's "War on Terror”: September 11 and Uighur Separatism', Foreign Affairs, Vol. 81, No. 4 (2002), pp. 8-12 \& Russell Ong, 'China and the US War on Terror’, Korean Journal of Defense Analysis, Vol. 18, No. 2 (Summer 2006), pp. 95-116.

5 Yuchao Zhu and Dongyan Blachford, 'China's Fate as a Multinational State: A Preliminary Assessment', Journal of Contemporary China, Vol. 15, (May 2006), p. 330. The Xinjiang Uyghur Autonomous Region is China's largest administrative unit and is populated by thirteen ethnic groups including the nationally dominant Han. According to the PRC's 2000 census the Uyghur population of Xinjiang stood at 8.3 million or $45 \%$ of the region's total population of 18.45 million, while the Han figure stood at 7.4 million or $40.5 \%$ of the population. See also Colin Mackerras, 'Ethnicity in China: The Case of Xinjiang’, Harvard Asia Quarterly, Vol. 8, No. 1, (Winter 2004), pp. 4-14.

${ }^{6}$ See Andrew D. W. Forbes, Warlords and Muslims: A Political History of Republican Sinkiang, $1912-$ 1949, (Oxford: Oxford University Press, 1986) \& David D. Wang, Under the Soviet Shadow: The Yining Incident. Ethnic Conflicts and International Rivalry in Xinjiang, 1944-1949, (Hong Kong: Chinese University Press, 1999).

${ }^{7}$ See James A. Millward, Eurasian Crossroads: A History of Xinjiang, (NY: Columbia University Press, 2007).

${ }^{8}$ Donald H. McMillen, Chinese Communist Power and Policy in Xinjiang, 1949-1977, (Boulder: Westview Press, 1979) \& James A. Millward and Nabijan Tursun, 'Political History and Strategies of Control, 1884-1978', in S. Frederick Starr (ed.), Xinjiang: China’s Muslim Borderland, (Armonk, NY: M. E. Sharpe, 2004), pp. 63-98. 
${ }^{9}$ McMillen, (note 8), Millward and Tursun (note 8) at page 73-80 \& Michael Dillon, Xinjiang: Ethnicity, Separatism and Control in Chinese Central Asia, (University of Durham, Dept. of East Asian Studies: Durham East Asian Papers 1, 1996), pp. 1-51.

${ }^{10}$ For example see, Nicolas Becquelin, 'Xinjiang in the Nineties', The China Journal, No. 44 (July 2000), pp. 75-98.

${ }^{11}$ Michael Clarke, 'Xinjiang and China's Foreign Relations with Central Asia, 1991-2001: Across the ‘Domestic-Foreign Frontier’, Asian Ethnicity, Vol. 4, No. 2 (June), pp. 217-21.

${ }^{12}$ See for example, Colin Mackerras, 'Xinjiang at the Turn of the Century: The Causes of Separatism', Central Asian Survey, Vol. 20, No. 3 (2001), pp. 289-303.

${ }^{13}$ See Kenneth Weisbrode, 'Central Eurasia, Prize or Quicksand? Contending Views of Instability in Karabakh, Ferghana and Afghanistan', Adelphi Papers, No. 338 (2001): 41-46, M. Eshan Ahrari, 'China, Pakistan and the "Taliban Syndrome”, Asian Survey, Vol. 40, No. 4, (July/August 2000), pp. 658-671 and Sean R. Roberts, “A “Land of Borderlands”: Implications of Xinjiang’s Trans-border Interactions’, in S. Frederick Starr (ed), Xinjiang: China’s Muslim Borderland (Armonk, NY; M. E. Sharpe, 2004), pp. 216-237.

${ }^{14}$ For the factors contributing to the formation of the 'Shanghai Five' and the SCO see, Clarke, 'Xinjiang and China's Foreign Relations with Central Asia': 221-223, Sally N. Cummings, 'Happier Bedfellows: Russia and Central Asia Under Putin', Asian Affairs, vol. 32, no. 2, (June 2001): 142-152 and Chien-peng Chung, 'The Shanghai Cooperation Organization: China's Changing Influence in Central Asia’, The China Quarterly, no.180, (December 2004): 990-992.

${ }^{15}$ For analysis of these links and of the scale of 'terrorism' in Xinjiang see, Michael Clarke, 'China's "War on Terror" in Xinjiang: Human Security and the Causes of Violent Uighur Separatism', Terrorism and Political Violence, Vol. 20, No. 2, (2008), pp. 271-301 \& James A. Millward, 'Violent Separatism in Xinjiang: A Critical Assessment' Policy Studies 6, (Washington: East-West Center, 2004).

${ }^{16}$ See for example, Nicolas Becquelin, 'Staged Development in Xinjiang, China Quarterly, Vol. 178, (June 2004), pp. 358-378, Gardner Bovingdon, 'The Not-So-Silent Majority: Uyghur Resistance to Han Rule in Xinjiang’, Modern China, Vol. 28, No. 1 (January 2002), pp. 39-79, Michael Clarke, 'China's Internal Security Dilemma and the "Great Western Development": The Dynamics of Integration, Ethnic Nationalism and Terrorism in Xinjiang', Asian Studies Review, Vol. 31 (September 2007), pp. 323-342, Graham E. Fuller and Jonathan Lipman, 'Islam in Xinjiang', in S. Frederick Starr (ed), Xinjiang: China’s Muslim Borderland (Armonk, NY; M. E. Sharpe, 2004), pp. 320-352 \& Amnesty International, People's Republic of China: Uighurs Fleeing Persecution as China Wages its 'War on Terror'.

${ }^{17}$ For the alternation of the 'soft' and 'hard' approaches see, Yitzhak Shicor, 'Blow Up: Internal and External Challenges of Uyghur Separatism and Islamic Radicalism to Chinese Rule in Xinjiang', Asian Affairs: An American Review, Vol. 32, No. 2 (Summer 2005), pp. 126-129, Mackerras (note 5) at pages 4-14 \& Fuller and Lipman, 'Islam in Xinjiang'.

${ }^{18}$ For the contours of the 'Strike Hard' campaigns nationally see, Susan Trevaskes, 'Severe and Swift Justice in China', British Journal of Criminology, Vol. 47 (2007), pp. 23-41 and for their impact in Xinjiang see Marika Vicziany, 'State Responses to Islamic Terrorism in Western China and Their Impact on South Asia’, Contemporary South Asia, Vol. 12, No. 2 (2003), pp. 243-262.

${ }^{19}$ Vicziany (note 18) at page 246.

${ }^{20}$ Michael Clarke, 'China’s Strategy in Xinjiang and Central Asia: Toward Chinese Hegemony in the ‘Geographic Pivot of History’?’, Issues \& Studies, Vol. 41, No. 2 (June 2005), pp. 99-103. 
${ }^{21}$ See Human Rights Watch, Devastating Blows: Religious Repression of Uighurs in Xinjiang, (1 April 2005), p. 5 available at http://www.unhcr.org/refworld/docid/42c3bcf20.html. Accessed 13 September 2008.

${ }^{22}$ Information Office of the State Council of the PRC, 'East Turkistan Forces Cannot Get Away with Impunity’ \& Denny Roy, 'China and the War on Terrorism’, Orbis, (Summer 2002), pp. 511-521.

${ }^{23}$ See Clarke (note 15) at p. 291 \&, Joshua Kurlantzick, 'China's Dubious Role in the War on Terror', Current History, Vol. 102, No. 668 (December 2003), pp. 432-438.

${ }^{24}$ See Aaron L. Friedberg, '11 September and the Future of Sino-American Relations', Survival, Vol. 44, No. 1 (Spring 2002), pp. 34-36 \& Jia Qingguo, 'Learning to Live with the Hegemon: Evolution of China's Policy Toward the US Since the End of the Cold War', Journal of Contemporary China, Vol. 14, No. 44, (August 2005), pp. 402-03.

${ }^{25}$ Joshua Kurlantzick, 'Repression and Revolt in China's Wild West', Current History, Vol. 103, No. 674, (September 2004), pp. 262-267.

${ }^{26}$ See Amnesty International, People's Republic of China: China's Anti-Terrorism Legislation and Repression in the Xinjiang Uighur Autonomous Region, (March 2002), pp. 1-22 \& Human Rights in China, China: Minority Exclusion, Marginalization and Rising Tensions, (London: Minority Rights Group International, February 2007), pp. 1-40.

${ }^{27}$ See Rosemary Foot, 'Collateral Damage: Human Rights Consequences of Counterterrorist Action in the Asia-Pacific', International Affairs, Vol. 81, No. 2 (2005), p. 413 \& Conor Gearty, 'Terrorism and Human Rights', Government and Opposition, Vol. 42, No. 3 (2007), pp. 340-342.

${ }^{28}$ Pouyan Afshar Mazandaran, 'An International Legal Response to an International Problem: Prosecuting International Terrorists’, International Criminal Law Review, Vol. 6 (2006), p. 512.

${ }^{29}$ Joan Fitzpatrick, 'Speaking Law to Power: The War against Terrorism and Human Rights', European Journal of International Law, Vol. 14, No. 2 (2003), p. 244.

${ }^{30}$ Mazandaran (note 28) at page 515.

${ }^{31}$ Mazandaran (note 28) at pages 515-517.

${ }^{32}$ United Nations, Convention against the Taking of Hostages, New York, 17 December 1979 available at http://untreaty.un.org/english/treatyevent2003/Treaty_15.htm. Accessed 30 November 2008.

${ }^{33}$ United Nations, Resolution Adopted by the General Assembly - Measures to Eliminate International Terrorism, $56^{\text {th }}$ Session of the General Assembly, New York, 24 January 2002, A/RES/56/88.

${ }^{34}$ Mazandaran (note 28) at page 516.

${ }^{35}$ See Clarke (note 15) at page 291. For an example of China’s agreements with neighbouring Central Asian states see for example, Ministry of Foreign Affairs of the PRC, 'Joint Statement Between the People's Republic of China and the Kyrgyz Republic on Deepening Good Neighborliness, Friendship and Cooperation', 20 August 2007, available at http://www.fmprc.gov.cn/eng/wjdt/2649/t355574.htm \& Ministry of Foreign Affairs of the PRC, 'Joint Statement Between the People's Republic of China and the Republic of Tajikistan on Deepening Good Neighborliness, Friendship and Cooperation', 27 August 2008, available at http://www.fmprc.cn/eng/wjdt/2649/t511334.htm. Accessed 30 September 2008.

${ }^{36}$ See for example, Fei-ling Wang, "Preservation, Prosperity and Power: What Motivates China's Foreign Policy”, Journal Contemporary China, Vol. 45, No. 14, (November 2005), pp. 669-94 \& Evan S. Medeiros and M. Taylor Fravel, 'China's New Diplomacy', Foreign Affairs, Vol. 82, No. 22, (Nov/Dec 2003), pp. 22-36. 
${ }^{37}$ See for example, Chih-yu Shih, 'Breeding a Reluctant Dragon: Can China Rise to Partnership and Away from Confrontation', Review of International Studies, Vol. 31, No. 4 (2005), pp. 757-760, Marc Lanteigne, China and International Institutions: Alternate Paths to Global Power, (London: Routledge 2005) and Avery Goldstein, 'The Diplomatic Face of China's Grand Strategy: A Rising Power's Emerging Choice', The China Quarterly, No. 168, (December 2001), pp. 835-864.

${ }^{38}$ See 'Amendment III to the Criminal Law of the People's Republic of China' in Criminal Law of the People’s Republic of China, (Beijing: China Legal Publishing House, 2002), p. 289.

${ }^{39}$ The subsequent citations are from 'Amendment III to the Criminal Law of the People's Republic of China', pp. 289-290.

${ }^{40}$ See Amnesty International (note 26) at pages 13-15 \& Amnesty International (note 2) at pages

41 Amnesty International, People's Republic of China: China's Anti-Terrorism Legislation and Repression in the Xinjiang Uighur Autonomous Region: 13.

42 Li Jingrong, ‘Counter-Terrorism Bureau Goes Public on “Eastern Turkistan” Terrorism', China.org, 23 December 2003 available at http://www.china.org.cn/english/2003/Dec/83114.htm. Accessed 12 November 2008.

${ }^{43}$ Ibid.

${ }^{44}$ Ibid.

${ }^{45}$ Ibid.

${ }^{46}$ Qingguo (note 24) at pages 402-04.

${ }^{47}$ See Amnesty International (note 26) \& Human Rights Watch (note 21).

48 '18, 000 Uygurs Arrested for “Security Threats” Last Year', South China Morning Post, 21 January 2006.

${ }^{49}$ See ‘In Custody: Recent Arrests in Xinjiang’, China Rights Forum, No. 1 (2004), pp. 1-7.

${ }^{50}$ Nicolas Becquelin, 'Criminalizing Ethnicity: Political Repression in Xinjiang', China Rights Forum, No. 1 (2004): 39-46.

${ }^{51}$ For a detailed account of the nature of these regulations see Human Rights Watch (note 21) at pages 18-24.

52 'Jiang Zemin, Zhu Rongji address National work conference', Xinhua, December 12, 2001 FBIS, December 19, 2001 [CHI-20011-1212].

${ }^{53}$ Human Rights Watch (note 21) at pages 25-26.

${ }^{54}$ Luisetta Mudie, 'China Confiscates Muslims Passports', Radio Free Asia, 27 June 2007 available at http://www.rfa.org/english/uyghur/uyghur_passports-20070627.html. Accessed 12 September 2008.

55 Jane McCartney, 'Crackdown on protests leaves Muslims without a prayer of joining Haj’, Times Online, $\quad 23 \quad$ November $2007 \quad$ available http://www.timesonline.co.uk/tol/news/world/asia/china/article2926471.htm. Accessed 12 September 2008.

${ }^{56}$ For the post-9/11 campaign against 'illegal religious activities' see Fuller and Lipman (note 16) at pages 333-34, 'China Bans Officials, State Employees, Children from Mosques', Radio Free Asia, February 6 2006, available at http://www.rfa.org/english/news/2006/02/06/uyghur_religion/ accessed 20 April 2006, Edward Wong, 'Wary of Islam, China Tightens a Vice of Rules', International Herald 
Tribune, 18 October 2008, available at http://www.iht.com/bin/printfriendly.php?id=17063989 accessed 4 November 2008 and 'Ramadan a time of repression: Chinese Muslims', Arab Times, 30 September 2008, p. 12.

${ }^{57}$ Human Rights Watch (note 21) at page 39.

58 'Xinjiang deepens the Strike hard against the 'three forces': A number of terrorist gangs already suppressed “Xinjiang”', China News Agency, January 172004.

59 'China convicts 50 to death in “terror crackdown”, Reuters, 13 September 2004.

60 'Visible achievements in the political strengthening of Kashgar Intermediate Court', Chinacourt.org, 9 February 2003, available at http://www.chinacourt.org/. Accessed 24 June 2007. This is the website of the Supreme People's Court.

${ }^{61}$ Amnesty International (note 2).

${ }^{62}$ Paulette Chu Miniter, 'Taking a Stand for China’s Uighurs', Far Eastern Economic Review, Vol. 170, No. 2 (March 2007), pp. 27-29.

${ }^{63}$ Becquelin (note 48 ) at page 43.

${ }^{64}$ Human Rights Watch (note 21) at page 14.

65 'Pakistan Confirms its Troops Killed top Chinese “Terrorist”, AFP, 23 December 2003.

${ }^{66}$ 'For the first time Xinjiang reveals the six forms of sabotaging operations of the separatist forces in the ideological sphere', Xinjiang Information Network, February 1, 2002.

${ }^{67}$ For an excerpt of Yasin's story see Nurmuhemmet Yasin, 'Wild Pigeon', China Rights Forum, No. 4, (2004), pp. 88-90.

${ }^{68}$ Human Rights Watch (note 21) at page 14.

${ }^{69}$ See Becquelin (note 50) and Michael Dillon, 'Uyghur Language and Culture Under Threat in Xinjiang', Central Asia-Caucasus Analyst, 14 August 2002 available at http://www.cacianalyst.org/view_article.php?articleid=23. Accessed 13 March 2003.

${ }^{70}$ Human Rights Watch (note 21) at page 13.

${ }^{71}$ See for example, Gulnoza Saidazimova, 'Uyghurs Hit By Autocratic States' Cooperation with Beijing', Eurasianet, 29 April 2006 available at http://www.eurasianet.org accessed 28 May 2006 and Alex Neve, 'Tortured Abroad? Forgotten at Home”, Toronto Star, 29 February 2008 available at http://thestar.com/printArticle/308095. Accessed 3 March 2008.

72 'Xinjiang Terrorist Sentenced to Life', China Daily, 19 April 2007 available at http://www.chinadaily.com.cn/china/2007-04/19/content_854515.htm. Accessed 2 July 2007.

${ }^{73}$ Geoffrey York, 'Celil Appeal Rejected by Chinese Court', Globe and Mail, July 10 2007, posted online at the Uyghur American Association http://uyghuramerican.org. Accessed 3 March 2008.

${ }^{74}$ Mukhamedov, Rustam 'Uyghurs in Kyrgyzstan under Careful Government Supervision', Central Asia-Caucasus Analyst, January $28 \quad 2004$ available at http://www.cacianalyst.org/view_article.php?articleid=2108 accessed 3 April 2004 and Amnesty International (note 2) at pages 19-31.

${ }^{75}$ Ibid \& Human Rights Watch (note 21) at pages 3-7. 
${ }^{76}$ Gerald Chan, 'China Joins Global Governance: The 10 Conundrums', in Wang Gungwu and Zheng Yongnian (eds.), China and the New International Order, (London: Routledge 2008), p. 173.

${ }^{77}$ See for example, Thomas Abrosio, 'Catching the Shanghai Spirit: How the Shanghai Cooperation Organization Promotes Authoritarian Norms in Central Asia', Asia-Europe Studies, Vol. 60, No. 8, (October 2008): 1321-1344.

${ }^{78}$ Chan (note 76) at page 173. 